\title{
Integrated Disease Management of Leaf Spot and Spotted Wilt of Peanut
}

\author{
E. G. Cantonwine, Former Graduate Student, A. K. Culbreath, Professor, K. L. Stevenson, Associate Professor, \\ R. C. Kemerait, Jr., Assistant Professor, and T. B. Brenneman, Professor, Department of Plant Pathology; \\ N. B. Smith, Assistant Professor, Department of Agricultural and Applied Economics; and B. G. Mullinix, Jr., Re- \\ search Statistician, Experimental Statistics Unit, The University of Georgia Coastal Plain Experiment Station, Tifton \\ 31793-0748
}

\begin{abstract}
Cantonwine, E. G., Culbreath, A. K., Stevenson, K. L., Kemerait, R. C., Jr., Brenneman, T. B., Smith, N. B., and Mullinix, B. G., Jr. 2006. Integrated disease management of leaf spot and spotted wilt of peanut. Plant Dis. 90:493-500.

Field experiments were carried out to evaluate the effects of integrated management of early leaf spot, caused by Cercospora arachidicola, and spotted wilt, caused by Tomato spotted wilt virus (TSWV), on peanut (Arachis hypogaea) using host resistance, two tillage systems, and varying fungicide programs. Effects on pod yield and economic return were assessed. Genotypes C-11-239 and Tifrunner demonstrated the best field resistance to TSWV, whereas cvs. DP-1 and GA01R and line C-28-305 were among the genotypes with the best leaf spot resistance. Epidemics of both diseases were comparable or suppressed in strip-tilled plots compared with conventionally tilled plots. Leaf spot intensity decreased with increased fungicide applications, but to a lesser degree with use of resistance and strip tillage. Yields and net returns were similar between tillage treatments in 2002 and lower in strip tillage in 2003. Genotypes with the greatest yields and returns were C-11-2-39, C-99R, and GA-01R. Returns were comparable among the four-, five-, and seven-spray programs in both years, despite differences in yield. The standard production system, Georgia Green in conventional tillage with seven sprays, resulted in lower returns than half the integrated systems tested in 2002, but had comparable or higher returns than nearly all systems in 2003. When significant, yields and returns were correlated with spotted wilt intensity to a greater degree than leaf spot intensity.
\end{abstract}

Additional keywords: Cercosporidium personatum, chlorothalonil, conservation tillage, economics, late leaf spot

In the southeastern United States, the most important foliar diseases of peanut (Arachis hypogaea L.) are spotted wilt, caused by Tomato spotted wilt virus (TSWV), early leaf spot, caused by Cercospora arachidicola $\mathrm{S}$. Hori, (teleomorph = Mycosphaerella arachidis Deighton), and late leaf spot, caused by Cercosporidium personatum (Berk. \& M. A. Curtis) Deighton, (teleomorph $=M$. berkeleyi Jenk.). These diseases occur every year in Georgia, although severity fluctuates by year and location. Pod losses of up to $50 \%$ can occur without disease management, and may be greater $(15,36)$.

No single management tool provides adequate control of spotted wilt; however, genetic, chemical, and cultural practices, such as cultivar selection, planting date, plant population, row pattern, tillage practice, and in-furrow insecticide, can reduce disease risk $(9,15)$. Frequent fungicide

Corresponding author: A. K. Culbreath

E-mail: spotwilt@tifton.uga.edu

Accepted for publication 15 November 2005.

DOI: 10.1094/PD-90-0493

(C) 2006 The American Phytopathological Society applications are common for leaf spot management. The standard fungicide program for growers in Georgia includes an initial application 30 days after planting (DAP), followed by additional sprays at 14-day intervals, resulting in seven or more applications per season (30).

Two inexpensive practices that provide some suppression of spotted wilt and leaf spot diseases are planting cultivars with host resistance and preparing fields using strip tillage, a conservation tillage practice that consists of $15-$ to $20-\mathrm{cm}$ tilled strips. Host resistance to TSWV, Cercospora arachidicola, and Cercosporidium personatum is partial in peanut, resulting in a reduction of epidemic severity rather than immunity to disease $(12,14,15)$. In the past, lower yield potential often was associated with resistant cultivars; however, cultivars and breeding lines with moderate disease resistance and high yield potential are now available $(27,32)$. The cv. Georgia Green, planted to over $85 \%$ of the acreage in Georgia during 2003 (N. B. Smith, unpublished data), has good yield potential and field resistance to TSWV, but is susceptible to Cercospora arachidicola and Cercosporidium personatum (7).

In recent years, several new cultivars have been released and breeding lines developed that have greater levels of resistance to leaf spot or spotted wilt pathogens than Georgia Green. These include Florida MDR-98 and C-99R, released in 1998 and 1999, respectively, with better resistance to Cercospora arachidicola $(11,32)$, Cercosporidium personatum $(25,26)$, and TSWV $(16-19,23,38)$ than Georgia Green. The "high oleic" cv. Hull has resistance levels to $C$. personatum and TSWV similar to those of C-99R (24), and cv. DP-1 reportedly has levels of resistance to $C$. personatum and TSWV that are among the best of any cultivar currently available in the United States. (24). Hull and DP-1 also have been shown to have moderate resistance to Cercospora arachidicola (A. K Culbreath, unpublished data). GA-01R, released in 2001, has moderate resistance to $C$. arachidicola and TSWV (A. K. Culbreath, unpublished data). The breeding lines C-11-2-39, C-28-305, and C-34-24, developed by C. C. Holbrook with the United States Department of AgricultureAgricultural Research Service, have better resistance to $C$. arachidicola and TSWV than C-99R (11). For most of these genotypes, the response to tillage practices or varying levels of reduced fungicide inputs have not been documented.

Strip tillage has been shown to suppress spotted wilt severity by as much as $42 \%$ compared with conventional tillage (29) When combined with four fungicide applications, strip tillage provided a level of leaf spot control that was comparable with that of conventionally tilled fields that received seven fungicide applications (32). This response was observed for Georgia Green, Florida MDR-98, and C-99R. Pod yields were comparable in conventional and striptillage plots over one 5-year study (29), but have been inconsistent in other tests $(28,32)$. The benefits of strip tillage for peanut production are not limited to disease management. Strip tillage and other conservation tillage practices increase soil fertility, reduce erosion, improve water infiltration, and save fuel, time, and labor (4). Use of conservation tillage for peanut production has increased over the past decade primarily due to depressed crop prices, increased energy costs, and a reduced labor force (29).

Production decisions regarding tillage and chemical inputs can significantly affect costs. The variable cost (fuel, labor, 
machinery repairs, and maintenance) of conventional deep-plow tillage is about $\$ 90 \mathrm{ha}^{-1}$, and conservation tillage can reduce this cost by up to $50 \%$ (37). The variable cost of each tractor-applied fungicide application is nearly $\$ 6 \mathrm{ha}^{-1}$ in addition to the cost of chemical (37). Potential savings in variable costs with strip tillage and reduced fungicide inputs can be as much as $\$ 180 \mathrm{ha}^{-1}$ (37), which is approximately $60 \%$ of the of the average crop value in Georgia in 2001 (41).

Monetary savings of strip tillage and fewer fungicide inputs may compensate for the economic impact of reduced yields in strip-tilled fields when they occur, and provide an opportunity for greater returns when yields are not affected. This study was carried out to compare disease management, pod yields and grades, and economics of peanut cultivars and advanced breeding lines that have equal or better field resistance to spotted wilt and leaf spot diseases than Georgia Green, and better resistance to at least one of these diseases than C-99R, under conventional and strip tillage with standard, reduced, or no fungicide applications. An economic comparison of these integrated disease management systems with the standard production system, consisting of cv. Georgia Green, conventional tillage, and a seven-application fungicide program for leaf spot control, also was conducted.

\section{MATERIALS AND METHODS}

Experimental design. A field experiment was carried out at the University of Georgia Coastal Plain Experiment Station, Rigdon Farm, Tifton GA in 2002 and 2003. Soil type was a Tifton loamy sand. Fields were planted to cotton (Gossypium hirsutum L.) the preceding year, and peanut 2 years prior, both grown with conventional tillage. Winter wheat (Triticum aestivum) was planted as a cover crop the previous fall. Disease history of fields included severe spotted wilt and leaf spot epidemics with minor soilborne pathogen problems when planted to peanut.

The experiment was laid out in a randomized split-split plot design with three replications. Treatments consisted of combinations of two tillage treatments (main plots), four fungicide programs (subplots), and eight genotypes (sub-subplots). Tillage treatments included conventional and strip tillage. Conventionally tilled plots were mowed and disked twice before the soil was deep turned with a switch plow, 20 to $25 \mathrm{~cm}$ deep, and bedded with a disk bedder. Ethalfluralin (Sonolan HFP 3.0; Dow AgroScience LLC, Indianapolis, IN) at $0.95 \mathrm{~kg}$ a.i. ha ${ }^{-1}$ and S-metoalochlor (Dual Magnum 8E; Syngenta Crop Protection, Inc., Greensboro, NC) at $1.68 \mathrm{~kg}$ a.i. $\mathrm{ha}^{-1}$ were incorporated into the tilled beds. In the strip-tillage plots, the cover crop was treated with glyphosate (Roundup 4 EC; Monsanto, Kansas City, MO) at $1.2 \mathrm{~kg}$ a.i. $\mathrm{ha}^{-1}$. A subsoil shank attached to a strip-till implement (Kelley Manufacturing Co., Tifton, GA) loosened the plow pan $33 \mathrm{~cm}$ beneath the row, while the implement tilled strips approximately 20 to $25 \mathrm{~cm}$ wide, as described by Monfort et al. (32). Genotype plots were $6.0 \mathrm{~m}$ long, separated by $2.4-\mathrm{m}$ alleys. The genotypes tested were cvs. Georgia Green, C-99R, Hull, GA-01R, and DP-1 and breeding lines C-11-2-39, C-28305 , and C-34-24 (recently released as Tifrunner). Peanut seed was planted to 91$\mathrm{cm}$-spaced single rows at a rate of 24 seed $\mathrm{m}^{-1}$ of row on 17 May 2002 and 30 seed $\mathrm{m}^{-1}$ of row on 20 May 2003 using a cone planter. Stand counts were recorded after peanut emergence and additional seed were hand planted in empty spaces greater than $20 \mathrm{~cm}$ in 2002 and $15 \mathrm{~cm}$ in 2003 . Fungicide programs consisted of calendarbased applications of chlorothalonil (Bravo Weatherstik 720 F; Syngenta Crop Protection, Inc.) at $1.26 \mathrm{~kg} \mathrm{ha}^{-1}$. The first spray was applied at approximately 30 DAP, followed by sprays at 14-, 21-, or 28-day intervals, resulting in programs of seven (seven-spray), five (five-spray), and four applications (four-spray), respectively. A nontreated control (zero-spray) also was included. Fungicides were applied with a tractor-propelled boom sprayer under 345 $\mathrm{kPa}$ pressure in 115 liters of water $\mathrm{ha}^{-1}$. In 2002, chlorothalonil was applied at 32,46 , $59,73,87,101$, and 115 DAP for the seven-spray program; 32, 53, 73, 91, and 115 DAP for the five-spray program; and $32,59,87$, and 115 DAP for the four-spray program. In 2003, spray dates were 30,43 , 57, 71, 84, 96 (reapplied at 103 DAP due to wash off by rain), and 113 DAP for the seven-spray program; 30, 50, 71, 91, and 113 DAP for the five-spray program; and $30,57,84$, and 113 DAP for the four-spray program. Acephate (Orthene $75 \mathrm{~W}$; Valent U.S.A. Corporation, Walnut Creek, CA) at $0.84 \mathrm{~kg}$ a.i. $\mathrm{ha}^{-1}$ was applied 13 DAP both years for early-season control of tobacco thrips (Frankliniella fusca Hinds). Acephate at the same rate was applied 106 DAP in 2003 at $0.42 \mathrm{~kg}$ a.i. ha ${ }^{-1}$ with diflubenzuron (Dimilin 2L; Crompton Chemical, Middlebury, CT) at $0.07 \mathrm{~kg}$ a.i. $\mathrm{ha}^{-1}$ at 108 DAP in 2002 for late-season control of feeding insects. No postplanting herbicide applications were necessary for conventional tillage plots; however, in the strip-tillage plots, bentazon (Basagran 4 EC; BASF Corporation, Research Triangle Park, NC) at $0.84 \mathrm{~kg}$ a.i. $\mathrm{ha}^{-1}$ and petroleum oil (Agri-Oil, ChemNut, Albany, GA) surfactant was applied 21 DAP, and a mixture of bentazon at 0.84 $\mathrm{kg}$ a.i. $\mathrm{ha}^{-1}$, 2,4-DB (Butyrac 175; Bayer CropScience, Research Triangle Park, NC) at $0.25 \mathrm{~kg}$ a.i. $\mathrm{ha}^{-1}$, and petroleum oil was applied 43 DAP in 2002. In 2003, a mixture of clethodim (Select 2 EC; Valent U.S.A. Corp.) at $0.14 \mathrm{~kg} \mathrm{a.i.} \mathrm{ha}^{-1}$, bentazon at $0.62 \mathrm{~kg}$ a.i. $\mathrm{ha}^{-1}$, and petroleum oil was applied to the strip-till plots 15 DAP. Cal- cium sulfate was applied to all plots as gypsum at $1,120 \mathrm{~kg} \mathrm{ha}^{-1} 52$ DAP in 2002 and 672 and $560 \mathrm{~kg} \mathrm{ha}^{-1} 55$ and 71 DAP, respectively, in 2003. The split application of gypsum in 2003 was due to a limited supply at the initial date. The field received $28 \mathrm{~cm}$ of rainfall and $17 \mathrm{~cm}$ of irrigation in 2002 , and $54 \mathrm{~cm}$ of rainfall and $3 \mathrm{~cm}$ of irrigation in 2003.

Disease assessment. Spotted wilt was evaluated 101 DAP in 2002 and 107 DAP in 2003. Spotted wilt intensity was determined in each plot using a disease intensity rating that represents a combination of incidence and severity. The number of 0.3$\mathrm{m}$ portions of row containing severely stunted, chlorotic, wilted, or dead plants was counted for each plot and converted to a percentage of row length for comparison of treatments (19).

Leaf spot severity per plot was estimated using the Florida 1-to-10 scale rating system, where $1=$ no leaf spot; $2=$ very few lesions on the leaves, none on the upper canopy; 3 = few lesions on the leaves, very few on the upper canopy; $4=$ some lesions, with more on the upper canopy, $5 \%$ defoliation; $5=$ lesions noticeable even on upper canopy, 20\% defoliation; 6 $=$ lesions numerous and very evident on upper canopy, $50 \%$ defoliation; $7=$ lesions numerous on upper canopy, $75 \%$ defoliation; $8=$ upper canopy covered with lesions, $90 \%$ defoliation; $9=$ very few leaves remaining and those covered with lesions, $98 \%$ defoliation; and $10=$ plants completely defoliated and killed by leaf spot (13). Leaf spot severity was assessed when symptoms first appeared (89 and 59 DAP in 2002 and 2003, respectively) and continued at 7- to 22-day intervals until harvest. Final percentage defoliation (defoliation) was estimated from the Florida scale rating taken just before peanut plants were inverted. Area under the disease progress curve (AUDPC) was computed for each plot using leaf spot intensity ratings (34), and standardized by dividing AUDPC by the number of days from the first to last rating.

Pod yield and grade. Peanut pods were harvested based on maturity class. Plots of Georgia Green, a medium maturity cultivar, were inverted 129 DAP in 2002 and 132 DAP in 2003. Plots of all other genotypes, which are considered late maturing, were inverted 140 DAP in 2002 and 145 DAP in 2003. Peanut pods were harvested mechanically 7 to 11 days after inverting, and pod yields were determined by weighing harvested pods after they were dried and adjusted to $10 \%$ (wt/wt) moisture. One 1,000-g sample of harvested pods per plot was cleaned, and non-pod materials were weighed. The percentage of kernels that were immature, damaged, and sound was determined from one 500-g sample of cleaned pods using commercial grading equipment according to official FederalState Inspection Service methods. Pod 
grades were defined as percent total sound mature kernels (TSMK).

Economic returns. Crop value was determined for each plot using the following formula derived from the 2003 pod price schedule: dollars per metric ton $=([\%$ TSMK $\times \$ 5.37]+[\%$ immature $\times \$ 1.54]$ ) $-([\%$ foreign material -4$] \times \$ 1.10)-(\%$ damaged deduction) $(1,2)$. There was no deduction for damaged kernels below $2 \%$ damaged kernels. The deduction was $\$ 3.75$ per metric ton if $2 \leq$ percent damaged $<3$, and $\$ 7.70$ if $3 \leq$ percent damaged $<4$ (2).

Production costs were estimated from Smith (37) to reflect total input costs of each treatment, including general production costs. The estimated cost for herbicide chemicals was $\$ 111.81 \mathrm{ha}^{-1}$ in conventional tillage and $\$ 119.32 \mathrm{ha}^{-1}$ in strip tillage. Preharvest fuel cost set at $\$ 0.30$ liter $^{-1}$ was $\$ 18.51 \mathrm{ha}^{-1}$ in conventional tillage and $\$ 5.40 \mathrm{ha}^{-1}$ in strip tillage, and machinery repair and maintenance was
$\$ 37.46 \mathrm{ha}^{-1}$ in conventional tillage and $\$ 28.98 \mathrm{ha}^{-1}$ in strip tillage. The estimated cost of labor set at $\$ 9.25 \mathrm{~h}^{-1}$ was $\$ 94.35$ $\mathrm{ha}^{-1}$ in conventional tillage and $\$ 74.00 \mathrm{ha}^{-1}$ in strip tillage, and operation capital interest was $\$ 15.47 \mathrm{ha}^{-1}$ in conventional tillage and $\$ 14.52 \mathrm{ha}^{-1}$ in strip tillage. Seed cost was computed using the following equation: seed cost $=\left(\right.$ seed price $\left(\$ \mathrm{~kg}^{-1}\right) \times$ seed $\mathrm{kg}^{-1} \times$ seed ha $\left.{ }^{-1}\right)$. Seed ha ${ }^{-1}$ was based on seeding rate, which was 143,500 in 2002 and 179,400 in 2003 . Seed price was determined using the 2004 cultivar distribution price. An average price was used for genotypes not available for purchase. Seed price estimates used were $\$ 1.19 \mathrm{~kg}^{-1}$ for Georgia Green, $\$ 1.26 \mathrm{~kg}^{-1}$ for C-99R, and $\$ 1.23 \mathrm{~kg}^{-1}$ for the other genotypes. The number of seed $\mathrm{kg}^{-1}$ was 1,819 for Georgia Green; 1,488 for C-99R, Hull, and GA$01 \mathrm{R}$; and 1,653 for DP-1, based on data reported by the University of Georgia State Wide Variety Testing Program (20-22);

Table 1. Effect of peanut genotype on spotted wilt severity by tillage in 2002 and across tillage in $2003^{\mathrm{a}}$

\begin{tabular}{lcccc}
\hline & \multicolumn{2}{c}{$\mathbf{2 0 0 2}^{\mathbf{b}}$} & & $\mathbf{2 0 0 3}^{\mathbf{c}}$ \\
\cline { 2 - 3 } Genotype & Conventional tillage & Strip tillage & & Across tillage* $^{*}$ \\
\hline C-11-2-39 & 2.9 & 2.7 & 1.8 \\
Tifrunner & 5.4 & 4.2 & 2.4 \\
DP-1 & 8.5 & 7.5 & 5.7 \\
GA-01R & 9.4 & 9.2 & 7.1 \\
C-99R & 12.7 & 10.4 & 4.7 \\
Hull & 19.4 & $10.0^{*}$ & 4.9 \\
C-28-305 & 22.7 & $11.1^{*}$ & 6.7 \\
Georgia Green & 21.7 & $12.9^{*}$ & 6.9 \\
LSD & \multicolumn{3}{c}{$3.9, \mathrm{df}=112$} & \\
\hline
\end{tabular}

${ }^{a}$ Least square means from Proc MIXED of percent of linear plot row severely affected by spotted wilt. Asterisks indicate significant differences between conventional tillage and strip tillage within a genotype in 2002 (least significant difference $[\mathrm{LSD}]=5.4, \mathrm{df}=17.4)$ and across genotypes in $2003(P<$ 0.01 , severity $=6.1 \%$ in conventional tillage and $4.0 \%$ in strip tillage).

b There was a significant interaction between tillage and genotype in $2002(P<0.01)$; therefore, genotypes were compared within tillage treatments.

${ }^{c}$ There was no interaction between tillage and genotype in $2003(P>0.05)$; therefore, genotypes were compared across tillage systems. and 1,764 for the three breeding lines $(\mathrm{C}$. C. Holbrook, personal communication). The additional production cost that did not differ among treatments was $\$ 383.38 \mathrm{ha}^{-1}$. Net returns were determined by subtracting variable production costs from crop value estimates.

Statistical analysis. Data were analyzed using Proc MIXED with ddfm = satterth option on the model statement (SAS v.8.3; SAS Institute, Cary, NC), unless otherwise stated. Main effects were considered significant when $P<0.05$. Fisher's least significant difference (LSD) values were computed using standard error and $t$ values of adjusted degrees of freedom. If an interaction was significant, the above Fisher's LSD was further adjusted to reflect use of the interaction term as a source of error if the $F$ test for the main effect using the appropriate interaction showed the main effect to be significant; otherwise, only the interaction means were presented. Net returns of integrated systems were compared with the standard system, Georgia Green with a seven-spray program under conventional tillage, by setting the three-way interaction (tillage-fungicide-genotype) as the only effect in the model statement.

\section{RESULTS}

Disease assessment. Spotted wilt was more severe in 2002 than 2003 (Table 1). Despite a significant interaction between tillage and genotype in $2002(P<0.01)$, spotted wilt incidence was lower for C-112-39 than any other genotype except Tifrunner, and Georgia Green and C-28-305 were among the genotypes with the highest spotted wilt levels (Table 1). Spotted wilt was similar in strip-tilled and conventionally tilled plots in 2002, with 8.5 and $12.8 \%$ row length severely affected, respectively $(P=0.06)$. However, the three cultivars with the highest spotted wilt rat-

Table 2. Effects of tillage and peanut genotype on leaf spot intensity across fungicide treatments in 2002 and $2003^{a}$

\begin{tabular}{|c|c|c|c|c|c|c|c|}
\hline \multirow[b]{3}{*}{ Genotype } & \multicolumn{4}{|c|}{2002} & \multicolumn{3}{|c|}{2003} \\
\hline & \multicolumn{2}{|c|}{ Defoliation $^{b, c}$} & \multicolumn{2}{|c|}{ AUDPC $^{c, d}$} & \multirow{2}{*}{$\begin{array}{c}\text { Defoliation }^{\mathrm{b}, \mathrm{e}} \\
\text { Across tillage* }^{*}\end{array}$} & \multicolumn{2}{|c|}{ AUDPC ${ }^{\mathrm{c}, \mathrm{d}}$} \\
\hline & Conv & Strip & Conv & Strip & & Conv & Strip \\
\hline C-11-2-39 & 23.2 & $3.8^{*}$ & 2.69 & $1.95^{*}$ & 59.3 & 3.56 & $2.86^{*}$ \\
\hline Tifrunner & 35.8 & $13.8^{*}$ & 3.02 & $2.18^{*}$ & 64.8 & 3.70 & $3.02 *$ \\
\hline DP-1 & 10.0 & 1.1 & 2.51 & 2.00 & 39.7 & 2.93 & $2.59^{*}$ \\
\hline GA-01R & 20.3 & 7.7 & 2.70 & $2.08 *$ & 47.8 & 3.32 & $2.72 *$ \\
\hline C-99R & 32.8 & $5.4^{*}$ & 3.04 & $2.09 *$ & 64.4 & 3.78 & $3.20^{*}$ \\
\hline Hull & 27.1 & $6.7 *$ & 2.81 & 2.21 & 56.8 & 3.52 & $3.04 *$ \\
\hline C-28-305 & 23.1 & $4.7^{*}$ & 2.75 & $2.07 *$ & 51.8 & 3.33 & $2.86^{*}$ \\
\hline Georgia Green & 43.2 & $9.6^{*}$ & 3.12 & $2.12 *$ & 65.8 & 3.86 & $2.83^{*}$ \\
\hline LSD & \multicolumn{2}{|c|}{$6.1, \mathrm{df}=111$} & \multicolumn{2}{|c|}{$0.15, \mathrm{df}=112$} & $7.7, \mathrm{df}=29.5$ & \multicolumn{2}{|c|}{$0.13, \mathrm{df}=112$} \\
\hline
\end{tabular}

${ }^{a}$ Asterisks indicate significant differences between conventional tillage (Conv) and strip tillage (Strip) within a genotype for defoliation (least significant difference $[\mathrm{LSD}]=13.9, \mathrm{df}=4.26)$ and area under the disease progress curve $($ AUDPC; $\mathrm{LSD}=0.61, \mathrm{df}=2.8)$ in 2002 and for AUDPC $(\mathrm{LSD}=0.21, \mathrm{df}=$ $10.1)$ in 2003, and across genotypes for defoliation in $2003(P<0.01$, defoliation $=63.3 \%$ in conventional tillage and $49.2 \%$ in strip tillage $)$.

${ }^{\mathrm{b}}$ Least square means of AUDPC using Florida 1-10 leaf spot intensity ratings and standardized by dividing by the number of days from the first to last rating.

${ }^{\mathrm{c}}$ Least square means from Proc MIXED of percent defoliation of peanut canopy due to leaf spot diseases at digging.

${ }^{\mathrm{d}}$ There was an interaction between tillage and genotype in 2002 for defoliation $(P<0.01)$ and AUDPC $(P<0.01)$ and in 2003 for AUDPC $(P<0.01)$; therefore, genotypes were compared within tillage treatments in these cases.

e There was no interaction between tillage and genotype in 2003 for defoliation $(P=0.21)$; therefore, genotypes were compared across tillage systems after adjusting the LSD for the significant fungicide-genotype interaction $(P<0.01)$ 
ings in 2002, Georgia Green, Hull, and C28-305, had significantly less spotted wilt in the strip-tilled than conventionally tilled plots (Table 1). In 2003, spotted wilt was significantly lower in strip-tilled than conventionally tilled plots, with 4.0 and $6.1 \%$ row length severely affected, respectively $(P<0.01)$. The genotype main effect explained $53 \%$ of the variation observed for spotted wilt in 2002 and $60 \%$ in 2003, whereas tillage explained 15 and $36 \%$ these years, respectively. Fungicide did not affect spotted wilt (data not shown).

Early leaf spot was the predominant leaf spot disease in the study $(>90 \%)$, although some late leaf spot was observed late in the season in both years. Leaf spot epidemics were more severe in 2003 than 2002 (Table 2). Tillage, fungicide, and genotype main effects for defoliation and AUDPC were significant in both years. In most cases, there was a significant interaction between tillage and genotype. Under conventional tillage or across tillage, Georgia Green, C99R, and Tifrunner were among the genotypes with the highest levels of leaf spot, whereas DP-1, GA-01R, and C-28-305 were among the genotypes with the lowest levels of leaf spot (defoliation and AUDPC; Table 2). Although disease response to genotype was less consistent across years under strip tillage, Georgia Green and Tifrunner continued to be among the genotypes with the highest levels of leaf spot, whereas DP-1 had the lowest defoliation and AUDPC (Table 2).

In general, leaf spot severity decreased as the number of fungicide applications increased; however, in 2002, the difference in defoliation was not significant among the four-, five-, or seven-spray programs in the strip-tilled plots, and AUDPC values were comparable between the four- and five-spray programs under both tillage treatments (Table 3). Defoliation and AUDPC values were numerically lower or similar in strip-tilled plots with no chlorothalonil applications than in conven- tionally tilled plots that received five or four applications in 2002, and similar in strip-tilled plots that received five sprays and conventional tilled plots that received seven sprays in both years (Table 3 ).

Of the main effects tested, fungicide had the greatest impact on leaf spot severity. In 2002, the fungicide effect explained 45 and $40 \%$ of the variation in defoliation and AUDPC, respectively. In 2003, the fungicide effect explained 61 and $62 \%$ of the variation in defoliation and AUDPC, re- spectively. Tillage had a greater impact on leaf spot severity than genotype, with tillage explaining between 26 and $34 \%$ of the variation observed for defoliation and AUDPC, whereas genotype explained 1 to $7 \%$.

Pod yield and grade. Pod yields of all genotypes were higher in 2003 than 2002 (Table 4). Yield was affected by genotype in both years $(P<0.01)$ and tillage in 2003 $(P=0.03)$, but was not significantly affected by tillage in $2002(P=0.14)$. De-

Table 4. Effects of conventional and strip-tillage and peanut genotype on pod yields and net dollar returns over variable costs per hectare in 2002 and 2003

\begin{tabular}{|c|c|c|c|c|}
\hline \multirow[b]{3}{*}{ Year, genotype } & \multicolumn{4}{|c|}{ Tillage $^{\mathbf{a}}$} \\
\hline & \multicolumn{2}{|c|}{ Pod yield $\left(\mathrm{kg} \mathrm{ha}^{-1}\right)^{\mathrm{b}}$} & \multicolumn{2}{|c|}{ Net returns $\left(\$ h^{-1}\right)^{c}$} \\
\hline & Conventional & Strip & Conventional & Strip \\
\hline \multicolumn{5}{|l|}{2002} \\
\hline C-11-2-39 & 4,310 & $3,842 *$ & 890 & 701 \\
\hline Tifrunner & 3,923 & 3,734 & 733 & 649 \\
\hline DP-1 & 3,910 & 3,706 & 678 & 600 \\
\hline GA-01R & 4,310 & 3,598 & 856 & $543 *$ \\
\hline C-99R & 3,673 & 3,503 & 599 & 526 \\
\hline Hull & 3,429 & 3,408 & 495 & 496 \\
\hline C-28-305 & 3,280 & 3,009 & 426 & 335 \\
\hline Georgia Green & 2,663 & 2,873 & 189 & 286 \\
\hline LSD & \multicolumn{2}{|c|}{$349, \mathrm{df}=124$} & \multicolumn{2}{|c|}{$192, \mathrm{df}=21$} \\
\hline \multicolumn{5}{|l|}{2003} \\
\hline C-11-2-39 & 5,316 & $4,428 *$ & 1,279 & $950 *$ \\
\hline Tifrunner & 4,523 & 4,120 & 951 & 822 \\
\hline DP-1 & 4,313 & 3,872 & 835 & 682 \\
\hline GA-01R & 4,631 & 4,459 & 999 & 956 \\
\hline $\mathrm{C}-99 \mathrm{R}$ & 5,441 & $4,760 *$ & 1,333 & $1,034 *$ \\
\hline Hull & 4,625 & 4,164 & 976 & 791 \\
\hline C-28-305 & 4,726 & $3,690 *$ & 993 & $613 *$ \\
\hline Georgia Green & 4,340 & $3,192 *$ & 885 & $443 *$ \\
\hline LSD & \multicolumn{2}{|c|}{$463, \mathrm{df}=112$} & \multicolumn{2}{|c|}{$188, \mathrm{df}=112$} \\
\hline
\end{tabular}

${ }^{a}$ Asterisks indicate significant differences between conventional tillage and strip-tillage within a genotype for yield in 2002 (least significant difference [LSD] $=390$, $\mathrm{df}=28.1$ ), yield in 2003 (LSD = 515 , $\mathrm{df}=28.3$, net return in 2002, adjusted for the three-way interaction, $(\mathrm{LSD}=218, \mathrm{df}=21)$, and net return in $2003(\mathrm{LSD}=205, \mathrm{df}=33.8$ ).

${ }^{\mathrm{b}}$ Least square means from Proc MIXED of estimated weight of peanut pods per hectare after dried to $10 \%(\mathrm{wt} / \mathrm{wt})$. There was an interaction between tillage and genotype in $2002(P=0.02)$ and in 2003 $(P=0.04)$; therefore, genotypes were compared within tillage treatments.

${ }^{c}$ Least square means of estimated crop value using the 2003 peanut pod price schedule minus variable costs to production. There was a three-way interaction in $2002(P<0.05)$ and an interaction between tillage and genotype in $2003(P<0.05)$; therefore, genotypes were compared across tillage systems in 2002 after adjusting for the 3-way interaction, and in 2003.

Table 3. Effect of fungicide treatments on leaf spot intensity for each tillage system across genotype entries in 2002 and $2003^{a}$

\begin{tabular}{|c|c|c|c|c|c|c|c|}
\hline \multirow[b]{3}{*}{ Fungicide program $f$} & \multicolumn{4}{|c|}{2002} & \multicolumn{3}{|c|}{2003} \\
\hline & \multicolumn{2}{|c|}{ Defoliation $^{\mathrm{b}, \mathrm{c}}$} & \multicolumn{2}{|c|}{ AUDPC $^{\mathrm{c}, \mathrm{d}}$} & \multirow{2}{*}{$\begin{array}{c}\text { Defoliation }^{\mathrm{b}, \mathrm{e}} \\
\text { Across tillage }^{*}\end{array}$} & \multicolumn{2}{|c|}{ AUDPC $^{\mathrm{c}, \mathrm{d}}$} \\
\hline & Conv & Strip & Conv & Strip & & Conv & Strip \\
\hline Zero-spray & 53.0 & $19.7 *$ & 3.82 & $2.67 *$ & 85.9 & 4.33 & $3.57 *$ \\
\hline Four-spray & 31.4 & $5.6^{*}$ & 2.90 & $2.08 *$ & 66.1 & 3.66 & $3.02 *$ \\
\hline Five-spray & 21.7 & $1.1 *$ & 2.64 & $1.96^{*}$ & 47.9 & 3.23 & $2.73 *$ \\
\hline Seven-spray & 1.7 & 0.0 & 1.96 & 1.64 & 25.2 & 2.69 & $2.23 *$ \\
\hline LSD & \multicolumn{2}{|c|}{$9.6, \mathrm{df}=12$} & \multicolumn{2}{|c|}{$0.29, \mathrm{df}=12$} & $7.7, \mathrm{df}=29.5$ & \multicolumn{2}{|c|}{$0.12, \mathrm{df}=12$} \\
\hline
\end{tabular}

a Asterisks indicate significant differences between conventional tillage (Conv) and strip tillage (Strip) within a fungicide program for defoliation (least significant difference $[\mathrm{LSD}]=13.9, \mathrm{df}=6.0)$ and area under the disease progress curve $($ AUDPC; $\mathrm{LSD}=0.52, \mathrm{df}=4.2)$ in 2002, and for AUDPC $(\mathrm{LSD}=$ 0.22 , $\mathrm{df}=10.3)$ in 2003, and across fungicide programs for defoliation in $2003(P<0.01)$.

${ }^{\mathrm{b}}$ Least square means from Proc MIXED of percent defoliation of peanut canopy due to leaf spot diseases at digging.

${ }^{c}$ There was an interaction between tillage and fungicide in 2002 for defoliation $(P<0.01)$ and AUDPC $(P<0.01)$, and in 2003 for AUDPC $(P=0.05)$; therefore, fungicide programs were compared within tillage treatments in these cases.

${ }^{\mathrm{d}}$ Least square means of AUDPC using Florida 1-10 leaf spot intensity ratings and standardized by dividing by the number of days from the first to last rating.

e There was not a significant interaction between tillage and fungicide in 2003 for defoliation $(P=0.07)$; therefore, fungicide programs were compared across tillage systems after adjusting the LSD for the significant fungicide-genotype interaction $(P<0.01)$.

${ }^{\mathrm{f}}$ Number of chlorothalonil applications applied throughout the season. 
spite significant tillage-genotype interactions in both years, Georgia Green and C28-305 were consistently among the lowest yielding genotypes, whereas C-11-2-39 and C-99R were among the highest (Table 4). Relative to the other genotypes, yields of GA-01R were high under both tillage systems in 2002 and in strip-tilled plots in 2003, whereas yields of DP-1 and Tifrunner were relatively high in 2002 and among the lowest in 2003. Fungicide affected yield in both years $(P<0.01)$, but there were no differences among the four-, five-, and seven-spray programs in 2002 or between the five- and seven-spray programs in 2003, when the fungicidegenotype interaction was considered (Table 5).

Georgia Green, DP-1, and C-28-305 had the lowest pod grades, whereas C-11-2-39, Tifrunner, and C-99R were among the genotypes with the highest grades (Table $6)$. Use of conventional tillage resulted in higher grades than those in strip tillage in 2002 (TSMK $=72.9$ and $70.9 \%$, respectively; $P=0.01)$ and comparable grades in 2003 (TSMK $=74.5$ and $73.8 \%$, respectively; $P=0.08)$. Fungicide affected grades in $2002(P=0.01)$, but there was a significant interaction between fungicide and genotype $(P<0.01)$ that was greater than the fungicide main effect (data not shown). Fungicide did not significantly affect grades in $2003(P=0.54)$. Mean percent damaged kernels and percent foreign material for all plots was below the respective 1.4 and $4 \%$ deduction thresholds, with few exceptions that resulted in less than $\$ 1.32$ loss per metric ton of kernels. Mean percent immature kernels ranged from 2.6 to $11.4 \%$. Despite a significant three-way interaction both years, Georgia Green and DP-1 tended to have higher percent immature kernels than the other genotypes in the study (data not shown).

Economic returns. The cost of each fungicide spray was estimated at $\$ 23.09$ $\mathrm{ha}^{-1}$, which included labor, fuel, machinery repair, and chemical costs. Seed costs ranged from $\$ 93.94 \mathrm{ha}^{-1}$ for Georgia Green in 2002 to $\$ 151.49 \mathrm{ha}^{-1}$ for C-99R in 2003, but differences among genotypes were never more than $\$ 34.07 \mathrm{ha}^{-1}$ each year (data not shown).

Net returns were higher in 2003 than 2002 (Table 4). Genotype affected economic returns in both years $(P<0.01)$ despite a three-way interaction with tillage and fungicide in $2002(P<0.05)$ and twoway interaction with tillage in $2003(P<$ 0.05). C-11-2-39 showed consistently high returns, whereas Georgia Green was among the genotypes with the lowest returns (Table 4). The zero-spray fungicide program resulted in lower returns than the seven-spray regime in 2002 and all fungicide treatments in 2003 (Table 5). Economic returns were similar among the four-, five-, and seven-spray programs in both years (Table 5). Tillage did not affect net returns in 2002, with mean returns of $\$ 613.68 \mathrm{ha}^{-1}$ in conventional tillage and $\$ 522.05 \mathrm{ha}^{-1}$ in strip tillage $(P=0.19)$, but did in 2003 , with $\$ 1,038.77 \mathrm{ha}^{-1}$ in conventional tillage and $\$ 792.90 \mathrm{ha}^{-1}$ in strip tillage $(P=0.03)$.

In 2002, 33 of the 63 integrated treatment combinations resulted in significantly greater returns than the standard Georgia Green, conventional tillage, seven-spray system: 6 from the zero-spray program, 8 from the four-spray program, 8 from the five-spray program, and 11 from the sevenspray program (Fig. 1). In 2002, net returns from treatment combinations that included C-11-2-39, DP-1, GA-01R, and Tifrunner exceeded those of the standard system more often than other genotypes. None of the treatment combinations resulted in lower returns than the standard system in 2002. In 2003, only C-11-2-39 in conventional tillage with five sprays resulted in significantly greater returns than the standard system, whereas nine systems, four with Georgia Green, two with DP-1 and C-28-305, and one with Hull, all from strip tillage, had lower returns (Fig. 1).

Table 5. Effect of number of fungicide applications on peanut pod yields and net dollar returns over variable costs in 2002 and 2003

\begin{tabular}{|c|c|c|c|c|}
\hline \multirow[b]{2}{*}{ Fungicide $^{\mathbf{a}}$} & \multicolumn{2}{|c|}{2002} & \multicolumn{2}{|c|}{2003} \\
\hline & Yield $\left(\mathrm{kg} \mathrm{ha}^{-1}\right)^{\mathrm{b}, \mathrm{c}}$ & Return $\left(\$ h^{-1}\right)^{d, e}$ & Yield $\left(\mathrm{kg} \mathrm{ha}^{-1}\right)^{\mathrm{b}, \mathrm{f}}$ & Return $\left(\$ h^{-1}\right)^{d, f}$ \\
\hline Zero-spray & 3,173 & 487 & 3,706 & 715 \\
\hline Four-spray & 3,605 & 581 & 4,429 & 920 \\
\hline Five-spray & 3,625 & 571 & 4,739 & 1,012 \\
\hline Seven-spray & 3,889 & 612 & 4,775 & 989 \\
\hline LSD & $314, \mathrm{df}=21$ & $96, \mathrm{df}=21$ & $298, \mathrm{df}=21$ & $136, \mathrm{df}=12$ \\
\hline
\end{tabular}

${ }^{\text {a }}$ Fungicide program: number of chlorothalonil applications applied throughout the season; LSD = least significant difference.

${ }^{\mathrm{b}}$ Least square means from Proc MIXED of estimated weight of peanut pods per hectare after dried to $10 \%(\mathrm{wt} / \mathrm{wt})$

${ }^{\mathrm{c}}$ There was an interaction between fungicide and genotype for yield in $2002(P<0.05)$ that was not as great as the fungicide effect; therefore the LSD was adjusted for the interaction.

${ }^{\mathrm{d}}$ Least square means of estimated crop value using the 2003 peanut pod price schedule minus variable costs to production.

${ }^{\mathrm{e}}$ There was a 3-way interaction for net return in $2002(P<0.05)$ that was not as great as the fungicide effect; therefore the LSD was adjusted for the interaction.

${ }^{\mathrm{f}}$ There were no interactions with fungicide in 2003 for yield or net return.
Spotted wilt severity was negatively correlated with yield and economic returns in 2002, but not in 2003 (Table 7). Leaf spot AUDPC values were not correlated with yield or economic returns in either year, but final percent defoliation levels were negatively correlated with yield and net returns in both years.

\section{DISCUSSION}

Spotted wilt and leaf spot epidemics in the experimental fields were variable each year. However, this variation was reflective of disease pressures typical for peanut in Georgia. Average disease loss estimates for fields under standard fungicide programs have been as high as $3 \%$ for leaf spot (39) and $4.5 \%$ for spotted wilt (40) over the past 6 years in Georgia. Much of the yearly variation in leaf spot pressure can be explained by differences in the amount of rainfall during these years; nearly $50 \%$ less rainfall occurred during the 2002 growing season than in 2003. Leaf spot severity is highly dependent upon weather, especially rainfall (35). Little is known about the causes of annual variation in severity of spotted wilt epidemics, which are notoriously difficult to predict.

Spotted wilt was suppressed in striptilled plots in 2003, despite a low level of disease, and in 2002 for the genotypes with the least amount of resistance. In most cases, epidemics of leaf spot were suppressed in the strip-tilled plots compared with conventionally tilled plots. Exceptions typically occurred when disease was low in conventional tillage, due to naturally low disease pressure, enhanced host resistance, or fungicide use. Others have reported similar interactions of tillage and other factors that affect severity of spotted wilt and leaf spot diseases $(15,32)$.

The cause of spotted wilt suppression in strip tillage may be related to lower population numbers of thrips, the vector for TSWV. Mechanisms affecting population dynamics of thrips in strip tillage are un-

Table 6. Effect of peanut genotype on percent total sound mature kernels (TSMK) at harvest in 2002 and 2003

\begin{tabular}{lcc}
\hline & \multicolumn{2}{c}{ TSMK $(\boldsymbol{\%})^{\mathbf{a}}$} \\
\cline { 2 - 3 } Genotype & $\mathbf{2 0 0 2}^{\mathbf{b}}$ & $\mathbf{2 0 0 3}^{\mathbf{c}}$ \\
\hline C-11-2-39 & 73.5 & 74.6 \\
Tifrunner & 73.2 & 74.5 \\
DP-1 & 71.0 & 73.0 \\
GA-01R & 71.8 & 75.4 \\
C-99R & 72.8 & 74.8 \\
Hull & 72.6 & 74.2 \\
C-28-305 & 70.8 & 72.7 \\
Georgia Green & 69.3 & 73.9 \\
LSD & $1.1, \mathrm{df}=21$ & $1.1, \mathrm{df}=16$ \\
\hline
\end{tabular}

${ }^{a}$ Least square means from Proc MIXED of percent yield weight of TSMK.

b There was an interaction between fungicide and genotype in $2002(P<0.05)$ that was not as great as the genotype effect.

$c$ There were no interactions in 2003

${ }^{\mathrm{d}}$ LSD $=$ least significant difference. 
clear; however, it has been proposed that plant debris at the soil surface in strip-tilled fields interfere with the ability of thrips to find peanut plants (15). Recent work in our lab has demonstrated that leaf spot epidemics are delayed in strip tillage compared with conventional tillage due to fewer initial infections, and that the presence of cover crop residue at the soil surface appears to be partially responsible for the epidemic delay (10). It is important to point out that this and previous reports of leaf spot suppression by strip tillage have been for epidemics dominated by early leaf spot $(32,33)$. More research is necessary to establish the effect of tillage on late leaf spot epidemics.
Leaf spot severity in strip-tilled plots that received four or five applications of chlorothalonil in 2002 and five applications in 2003 was comparable with that in conventionally tilled plots that received seven sprays. This result corroborates the report by Monfort et al. (32) that leaf spot control with a four-spray, 21-28-21-28-day interval program in strip tillage was similar to a seven-spray, 14-day interval program in conventional tillage. Leaf spot intensity in the strip-tilled plots with no fungicide applications was comparable with leaf spot levels in conventionally tilled plots that received five sprays in 2002 and four sprays in 2003. This result suggests that management of leaf spot by strip tillage alone can be as good as an extended interval fungicide program that results in four to five fungicide applications of chlorothalonil in conventional tillage.

When spotted wilt pressure was high in 2002, management of this disease was an important consideration for the optimization of yields and net returns. This was not the case in 2003, when spotted wilt disease pressure was lower. Severity of leaf spot epidemics, as assessed by AUDPC, was not correlated with yields or net returns, but the amount of defoliation at harvest was a good predictor of both yield and net returns. The relationship between final
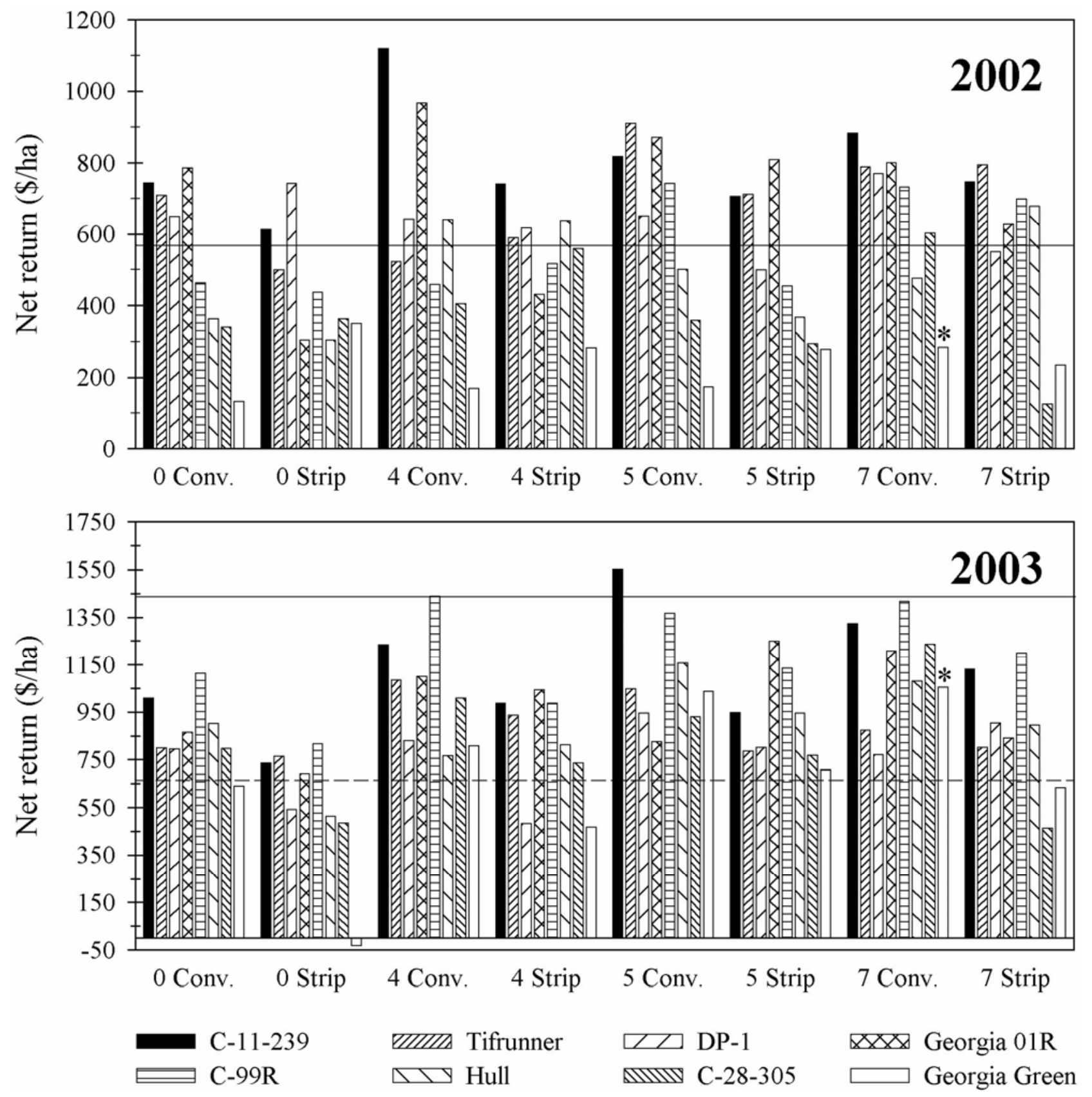

Fig. 1. Comparison of net returns of integrated management systems and the standard production practice $(*)$ in 2002 and 2003 . Systems varied by the number of fungicide applications (zero, four, five, or seven), tillage treatment (conventional [Conv.] or strip [Strip] tillage), and peanut genotype. The solid line indicates the net return above which systems are significantly greater than the standard (Georgia Green, seven-spray program, conventional tillage). The dashed line, when applicable, indicates the net return below which systems are significantly less than the standard. 
defoliation levels and yield loss has been documented for susceptible cultivars (35), and is most likely due to lost pods at digging because pegs weaken as defoliation levels increase (31). Yield loss induced by defoliation is not linear. Florunner, the industry standard runner-type cultivar from 1970 into the 1990s, tolerated as much as $40 \%$ defoliation before heavy yield losses occurred (3). In the present study, the absence of yield loss observed in response to different levels of defoliation suggests that the peanut genotypes included in this study also tolerate some amount of defoliation before incurring pod losses. More research is needed to determine the potential of tolerance to help reduce yield losses from leaf spot.

Of the factors investigated in this study, genotype had the greatest impact on yield and net returns. Although some of this effect can be attributed to disease resistance or tolerance, it is likely that variation in overall yield potential also plays a role. C-11-2-39 appears to be the most promising of the genotypes compared in this study with regard to consistent profits despite disease intensities. However, this breeding line is not suitable for large-scale commercial production because it produces a seed with a red testa that is not acceptable to shellers. C-99R does not have as much field resistance to TSWV as many of the other genotypes, but it does have great yield potential when spotted wilt severity is relatively low, as seen in 2003. Tifrunner was similar to Georgia Green in resistance to leaf spot, but has much better field resistance to TSWV and equal or better yield potential. Tifrunner and C-11-2-39 have the same parentage, but the seed testa color of Tifrunner is tan, like Georgia Green, and may be a viable alternative to Georgia Green when additional resistance to TSWV is desired. The yield and net returns of DP-1 and GA-01R were among the highest in 2002 but were lower in 2003 compared with the other genotypes. Germination was low for these lines in 2003 and, although seed were replanted, it is likely that there were some losses due to poor germination. DP-1 and some other lines from the University of Florida breeding program, such as Southern Runner, have a history of poor germination (A. K. Culbreath, unpublished data). Yield and net returns were more highly correlated with spotted wilt severity than leaf spot intensity; therefore, when correlations were significant, growers would be well advised to base cultivar selection on spotted wilt resistance rather than leaf spot resistance, especially because other options are available for leaf spot management. However, some of the breeding lines and cultivars offer improved resistance to both TSWV and leaf spot pathogens, and should work well in an integrated program where management of multiple diseases must be considered.

The savings incurred by strip tillage were not great enough to exceed the return potential of conventional tillage in 2002, or to compensate for losses to yield in striptilled plots in 2003. However, it is important to point out that these fields were in their first year of strip tillage, and it is common to see reduced yields during the first year of conservation tillage. A 6-year field study of peanut plots under continuous conventional or strip tillage with a peanut-cotton rotation resulted in lower pod yields in the strip-tilled plots than the conventionally tilled plots during the first year, but comparable yields between the tillage treatments after 3 years (C. C. Truman, personal communication). More research is necessary to assess disease suppression under continuous conservation tillage systems.

In general, the standard program consisting of Georgia Green, seven fungicide applications, and conventional tillage did not maximize net returns. However, strip tillage and reduced fungicide programs did not maximize returns either. It is important to note that opportunity (e.g., management time) and fixed (e.g., land and equipment) costs were not considered in this study. Both of these factors may add to the value of strip tillage and reduced fungicide inputs. For example, the time saved with strip tillage $\left(2 \mathrm{~h} \mathrm{ha}^{-1}\right)$ or fewer fungicide applications (22 min application ${ }^{-1} \mathrm{ha}^{-1}$ ) (37) could be invested in alternative income ventures. Fixed costs associated with the purchase of equipment is estimated to be $\$ 73 \mathrm{ha}^{-1}$ year $^{-1}$ less with strip tillage than conventional tillage (37). Increases in fuel costs also could make conservation tillage economically more favorable even if the yield differential observed in this study were consistent over time. In addition, economic incentives for conservation tillage practices by cost-share programs, such as the Conservation Reserve and Conservation Reserve Enhancement Programs, also may increase the economic potential of strip tillage.

Stem rot and limb rot, caused by Sclerotium rolfsii and Rhizoctonia solani, respectively, were not present at high levels in this study (data not shown); however, their management is of critical importance in many peanut fields in the southeastern United States $(5,6,41)$. Strip tillage has not been found to enhance severity of stem rot compared with conventional tillage $(29,32)$, but may aggravate limb rot severity because $R$. solani can survive saprophytically on plant debris and sclerotia are stimulated to germinate by organic matter in soils (8). Chlorothalonil is not affective against $S$. rolfsii or $R$. solani in peanut; however, other fungicides are available that have multipathogen activity and provide comparable or better leaf spot control. Chlorothalonil was selected in this study because the field histories of stem rot and limb rot indicated low risk of these diseases. In addition, the cost and activity of chlorothalonil was considered low relative to other fungicides, which provided a conservative estimate of the economic and disease management effects of the programs. Studies are underway to evaluate the relative levels of resistance of these genotypes to soilborne pathogens, and to explore impacts of integrating cultural practices, host resistance, and reduced application programs with various fungicides on disease development and economic returns when management of these diseases is considered as well.

\section{ACKNOWLEDGMENTS}

This research was supported in part by the Georgia Peanut Commission and the National Peanut Board. We thank M. Heath, S. Gremillion, S. Carter, S. Bertrand, A. McKeown, K. Parrish, and $\mathrm{K}$. Welch for their field assistance.

Table 7. Correlation coefficients and probabilities for linear relationships between intensity of spotted wilt and leaf spot (defoliation and AUDPC) diseases with peanut yields and net returns in 2002 and 2003.

\begin{tabular}{|c|c|c|c|c|c|c|}
\hline & \multicolumn{3}{|c|}{2002} & \multicolumn{3}{|c|}{2003} \\
\hline & Spotted wilta & Defoliation $^{b}$ & AUDPC $^{c}$ & Spotted wilt ${ }^{\mathrm{a}}$ & Defoliation $^{b}$ & AUDPC \\
\hline Yield $\left(\mathrm{kg} \mathrm{ha}^{-1}\right)^{\mathrm{d}}$ & -0.5632 & -0.2818 & -0.0971 & -0.0515 & -0.2875 & -0.0484 \\
\hline$P$ value & $<0.0001$ & $<0.0001$ & 0.1803 & 0.4784 & $<0.0001$ & 0.5053 \\
\hline Net return $\left(\$ h^{-1}\right)^{\mathrm{e}}$ & -0.5897 & -0.1479 & 0.0613 & -0.0744 & -0.1662 & 0.0678 \\
\hline$P$ value & $<0.0001$ & 0.0407 & 0.3981 & 0.3051 & 0.0212 & 0.3501 \\
\hline
\end{tabular}

\footnotetext{
${ }^{a}$ Least square means from Proc MIXED of percent of linear plot row severely affected by spotted wilt.

${ }^{\mathrm{b}}$ Least square means of percent defoliation of peanut canopy due to leaf spot diseases at digging.

${ }^{\mathrm{c}}$ Least square means of area under the disease progress curve (AUDPC) using Florida 1-10 leaf spot intensity ratings and standardized by dividing by the number of days from the first to last rating.

${ }^{\mathrm{d}}$ Least square means of estimated weight of peanut pods per hectare after dried to $10 \%$ (wt/wt).

${ }^{\mathrm{e}}$ Least square means of estimated crop value using the 2003 peanut pod price schedule minus variable costs to production.
} 


\section{LITERATURE CITED}

1. Anonymous. 2003. 2003 Crop peanut loan rates by type. Notice LP-1933, USDA-FSA, Washington, DC.

2. Anonymous. 2003. Peanut loan repayment and loanmaking enhancements using county release No. 501. Notice PS-454, USDA-FSA, Washington, DC.

3. Backman, P. A., and Crawford, M. A. 1984. Relationship between yield loss and severity of early and late leafspot diseases of peanut. Phytopathology 74:1101-1103.

4. Blevins, R. L., and Frye, W. I. 1993. Conservation tillage: an ecological approach to soil management. Adv. Agron. 51:34-77.

5. Bowen, K. L. 2003. Development of stem rot (caused by Sclerotium rolfsii) in peanut in Alabama. Peanut Sci. 30:120-128.

6. Bowen, K. L., Hagan, A. K., and Weeks, J. R. 1997. Number of tebuconazole applications for maximizing disease control and yield of peanut in growers' fields in Alabama. Plant Dis. 81:927-931.

7. Branch, W. D. 1996. Registration of 'Georgia Green' peanut. Crop Sci. 36:806.

8. Brenneman, T. B. 1997. Rhizoctonia diseases. Pages 30-31 in: Compendium of Peanut Diseases, 2nd ed. N. Kokalis-Burelle, D. M. Porter, R. Rodriguez-Kabana, D. H. Smith, and P. Subrahmanyam, eds. American Phytopathological Society Press, St. Paul, MN.

9. Brown, S., Todd, J., Culbreath, A., Baldwin, J., Beasley, J., Kemerait, B., and Prostko, E. 2003. Minimizing spotted wilt of peanut. Bull. 1165, Univ. Ga. Coop. Ext. Ser., Athens.

10. Cantonwine, E. G. 2005. The use of genetics and cultural practices to suppress foliar diseases of peanut and reduce fungicide requirements. Ph.D. thesis, University of Georgia, Athens.

11. Cantonwine, E. G., Culbreath, A. K., Holbrook, C. C., and Gorbet, D. W. 2002. Response of moderately resistant peanut breeding lines and cultivars to chlorothalonil for management of early leaf spot. (Abstr.) Proc. Am. Peanut Res. Educ. Soc. 34:92-93.

12. Chiteka, Z. A. 1987. Some components of resistance to late leaf spot (Cercosporidium personatum) in peanut (Arachis hypogaea L.). M.S. thesis, University of Florida, Gainsville.

13. Chiteka, Z. A., Gorbet, D. W., Shokes, F. M., Kucharek, T. A., and Knauft, D. A. 1988. Components of resistance to late leaf spot in peanut I. Levels of variability-implications for selection. Peanut Sci. 15:25-30.

14. Chiyembekeza, A. J. 1992. Inheritance of components of resistance to late leafspot in peanut. Ph.D. thesis, University of Florida, Gainsville

15. Culbreath, A. K., Todd, J. W., and Brown, S. L. 2003. Epidemiology and management of tomato spotted wilt in peanut. Annu. Rev. Phytopathol. 41:53-75.

16. Culbreath, A. K., Todd, J. W., Gorbet, D. W., Brown, S. L., Baldwin, J. A., Pappu, H. R., Holbrook, C. C., and Shokes, F. M. 1999. Response of early, medium, and late maturing peanut breeding lines to field epidemics of tomato spotted wilt. Peanut Sci. 26:100-106.

17. Culbreath, A. K., Todd, J. W., Gorbet, D. W., Brown, S. L., Baldwin, J., Pappu, H. R., and Shokes, F. M. 2000. Reaction of peanut cultivars to spotted wilt. Peanut Sci. 27:35-39.

18. Culbreath, A. K., Todd, J. W., Gorbet, D. W., Shokes, F. M., and Pappu, H. R. 1997. Field performance of advanced runner- and Virginiatype peanut breeding lines during epidemics of TSWV. Peanut Sci. 24:123-128.

19. Culbreath, A. K., Todd, J. W., Gorbet, D. W., Shokes, F. M., and Pappu, H. R. 1997. Field response of new peanut cultivar UF 91108 to tomato spotted wilt virus. Plant Dis. 81:14101415.

20. Day, J. L., Coy, A. E., Branch, W. D., May, O. L., LaHue, S. S., and Thompson, L. G., eds. 2002. 2001 Peanut, cotton, and tobacco performance tests. Rep. No. 677, Ga. Agric. Exp. Stn., Athens.

21. Day, J. L., Coy, A. E., LaHue, S. S., Branch, W. D., May, O. L., Thompson, L. G., and Rose, P. A., eds. 2004. 2003 Peanut, cotton, and tobacco performance tests. Rep. No. 692, Ga. Agric. Exp. Stn., Athens.

22. Day, J. L., Coy, A. E., LaHue, S. S., Branch, W. D., Thompson, L. G., Rose, P. A., and Beasley, J. P., eds. 2003. 2002 Peanut, cotton, and tobacco performance tests. Rep. No. 686, Ga. Agric. Exp. Stn., Athens.

23. Gorbet, D. W. 1998. University of Florida peanut breeding program. Soil Crop Sci. Soc. Fla. Proc. 58:16-18

24. Gorbet, D. W. 2003. New University of Florida peanut varieties for 2003. 03-2, Marianna NFREC Res. Rep., Marianna, FL.

25. Gorbet, D. W., and Shokes, F. M. 2002. Registration of 'C-99R' peanut. Crop Sci. 42:2207.

26. Gorbet, D. W., and Shokes, F. M. 2002. Registration of 'Florida MDR-98' peanut. Crop Sci. 42:2207-2208

27. Gorbet, D. W., Shokes, F. M., and Jackson, L. F. 1982. Control of peanut leafspot with a combination of resistance and fungicide treatment. Peanut Sci. 9:87-90.

28. Hartzog, D. L., and Adams, J. F. 1989. Reduced tillage for peanut production. Soil
Tillage Res. 14:85-90.

29. Johnson, W. C., III, Brenneman, T. B., Baker, S. H., Johnson, A. W., Sumner, D. R., and Mullinix, B. G., Jr. 2001. Tillage and pest management considerations in a peanut-cotton rotation in the southeastern coastal plain Agron. J. 93:570-576.

30. Kemerait, R. C., Brenneman, T. B., and Culbreath, A. K. 2005. Peanut disease control. Pages 122-123 in: 2005 Georgia Pest Management Handbook, Commercial ed. P. Guillebeau, ed. University of Georgia Cooperative Extension Series, Athens.

31. Knauft, D. A., Gorbet, D. W., and Norden, A. J. 1988. Yield and market quality of seven peanut genotypes as affected by leafspot disease and harvest date. Peanut Sci. 15:9-13.

32. Monfort, W. S., Culbreath, A. K., Stevenson, K. L., Brenneman, T. B., Gorbet, D. W., and Phatak, S. C. 2004. Effects of reduced tillage, resistant cultivars, and reduced fungicide inputs on progress of early leaf spot of peanut (Arachis hypogaea). Plant Dis. 88:858-864.

33. Porter, D. M., and Wright, F. S. 1991. Early leaf spot of peanuts: Effect of conservational tillage practices on disease development. Peanut Sci. 18:76-79.

34. Shaner, G., and Finney, R. E. 1977. The effect of nitrogen fertilization on the expression of slow-mildewing resistance in Knox wheat. Phytopathology 67:1051-1056.

35. Shokes, F. M., and Culbreath, A. K. 1997. Early and late leaf spots. Pages 17-20 in: Compendium of Peanut Diseases, 2nd ed. N. Kokalis-Burelle, D. M. Porter, R. RodriguezKabana, D. H. Smith, and P. Subrahmanyam, eds. American Phytopathological Society Press, St. Paul, MN.

36. Smith, D. H., and Littrell, R. H. 1980. Management of peanut foliar diseases. Plant Dis. 64:356-361

37. Smith, N. B. 2003. 2003 Georgia crop enterprise cost analysis. AGECON-94-010-S (Revised), Univ. Ga. Coop. Ext. Ser., Athens.

38. Wells, M. L., Culbreath, A. K., Todd, J. W. Brown, S. L., and Gorbet, D. W. 2002. A regression approach for comparing field resis tance of peanut cultivars to tomato spotted wilt tospovirus. Crop Prot. 21:467-474

39. Williams-Woodward, J. L., ed. 1999. 1998 Georgia plant disease loss estimates. Spec. Bull. 41-01, Univ. Ga. Coop. Ext. Ser., Athens.

40. Williams-Woodward, J. L., ed. 2003. 2002 Georgia plant disease loss estimates. Spec. Bull. 41-05, Univ. Ga. Coop. Ext. Ser., Athens.

41. Williams-Woodward, J. L., ed. 2004. 2003 Georgia plant disease loss estimates. Spec. Bull. 41-06, Univ. Ga. Coop. Ext. Ser., Athens. 